\title{
Bridging the Gap: Thinking Beyond the State in Child Protection
}

\begin{abstract}
This Comment discusses the limitations of state agencies such as child protection in managing long-term risk issues in isolated families in need of strong support systems. It concludes with a suggestion that is in line with the national framework on child protection: namely, that community members and community level support services working in tandem with child protection might be better positioned to effectively assist with the onerous task of child protection - especially where the state and parent(s) are unable to do so.
\end{abstract}

\section{Introduction}

The focus of this Comment ${ }^{1}$ is on the need to bridge the gap between the state and families in which children are the subject of a risk of harm report. This is located in the context of considerations on the limitations of state agencies, such as Community Services (CS), dealing with child protection - particularly in light of the recent case of Kiesha Abrahams and two similar cases in the last two years in New South Wales (NSW). Kiesha Abrahams was six years old when she was reported missing in August 2010. In April 2011, her body was found buried in bushlands northwest of her family home in Mount Druitt. The police suspect foul play and have since arrested and charged Kiesha's mother with murder and the stepfather has pleaded guilty to manslaughter (Australian Associated Press 2011a). Although the facts of the Abrahams case are not publicly known yet, the case bears some resemblance to the NSW cases of seven-year-old 'Ebony' in the Hunter region two years ago and two-year-old Dean Shillingsworth three years ago. Ebony (who cannot be named for legal reasons) and Dean suffered abuse, neglect and eventual death at the hands of their parents. Like Ebony and Dean, it appears that Kiesha may have been known to several state agencies such as CS (NSW Child Protection Service), the NSW Department of Education and NSW Health, prior to her death. Using these cases as a starting point into examining the limitations of state intervention, this Comment has a threefold purpose. First, it queries the community's response to Kiesha's death. Second, it examines the limitations of state agencies in protecting children from harm. Third, the Comment focuses on the distance between the state and the family, which is seen as impacting on the state's protective functions. Finally, the Comment concludes with a proposal for the need to think beyond the state on issues of child protection.

The themes in this Comment are informed by the information arising from my study of 40 filicide cases in New South Wales between 2000 and 2007 that were categorised as 'assault' in the National Coroners Information System. This Comment is based on part of my doctrinal thesis on filicide. 


\section{The community's response to a child's death}

The death of Kiesha Abrahams sparked community outrage directed at her alleged killers. There were some calls to introduce legislation, such as the so-called 'Kiesha's Law' that would address the problem of neglected children and empower the community to step up and take ownership and responsibility for children where parents fail (Lawrence 2011; Australian Associated Press 2011b). Such a knee-jerk response - poorly thought out policy and legislation based on a single case like the famous USA 'Megan's law' - may well lead to vigilantism and miscarriages of justice and provide no protection for children, as it would unfairly and arbitrarily single out families that are in need, instead of providing support for them. Looking closer at the proposal for Kiesha's Law, it seems its intention is to introduce mandatory life sentences for persons convicted of murdering a child (Liu and Thomas 2011). However, this law might do more harm than good because it removes judicial sentencing discretion and conflicts with a fundamental principle of criminal punishment, which is the rehabilitation of the offender. On the surface, it might satisfy the public's desire for vengeance through punishment as a form of retribution (Cowdery 1999:291). In reality, however, it would impact negatively on justice in individual cases, because it lessens the discretion of the decision-maker and the sentence may not be appropriate in all cases (Cowdery 1999:294). A mandatory life sentence might seem unduly harsh, for instance, if there were an existing child in the family or where the perpetrator acted under extenuating circumstances, such as mental illness, at the time of the offence.

Perhaps the underlying question that the community is, or should be, asking is whether state agencies are doing enough to protect children from harm. Maybe the state is too removed from families to recognise the risks of child endangerment and is struggling as surrogate parent to protect children. The following discussion focuses on some of the measures taken to address this contention, and questions if this perception of the state as distant and disconnected can be addressed by strengthening communities and their support networks to function in collaboration with the national framework on child protection (Council of Australian Governments 2009).

\section{Limitations of the state}

Both the report of the NSW Ombudsman (2006:7) and the report of the NSW Child Death Review Team (2008) on reviewable child deaths indicate that prior to 2006, the majority of children who were killed, as a result of abuse, neglect, murder or other suspicious circumstances, were known to state agencies at the time of death (Sim 2009:244). Since then, there have been changes to the Children and Young Persons (Care and Protection) Act 1998 (NSW) (CYPA) following Justice Wood's 2008 Inquiry into Child Protection Services. For instance, section 23 requires mandatory reporting of children at risk of significant harm. The impact of this amendment raises the threshold of harm by inserting the word 'significant' to mean grave (not trivial) and serious (not minor) harm. Its purpose is to re-focus child protection resources on the most urgent of cases in which an immediate response of intervention is warranted, irrespective of the family's consent. In spite of this renewed focus promising to streamline the organisation's burden, it raises questions whether $\mathrm{CS}$ is soundly equipped to tackle longstanding issues in the family such as domestic violence, child abuse and neglect, or to make decisions regarding long-term risk management in some families. The hard truth that appears to be emerging is: CS needs to 
recognise the limits of its current capabilities and the extent to which it can provide a reliable support network to families in crisis.

It is worth first contextualising that the difficulty CS faces when tackling long-term familial issues, such as child abuse in vulnerable and disadvantaged families, stems from its perceived physical and emotional distance from the family. At the heart of child protection is a child-centred focus on safety and wellbeing. In most cases, the best way to assess the wellbeing of a child is for a caseworker to visit the family to ascertain whether the harm reports are believable and verifiable. In particular, the public/private division between the family and the state is difficult to navigate. It is arguable that because the caseworker is not physically present on a daily basis to make a global and holistic assessment of the domestic situation, much risk assessment is reliant on secondary reporting from family members, follow-up visits and investigations by the caseworker, and medical checks on the child. Parents can sometimes be difficult to reach, and may refuse to co-operate, providing 'reasons' refusing the caseworkers' access to the child, such as occurred in Ebony's case.

Additionally, it is not difficult to see that many child protection decisions require the weighing up of complex moral, legal and psychosocial questions from afar, particularly where they concern decisions regarding intervention (Wilczynski 1995:193). The use of standardised risk assessment tools is a critical reminder that it is a remote and distant tool: not only does one template not fit all families, but much in the risk assessment instruments have little to do with protecting children effectively, and more to do with protecting organisations against blame when mistakes are made (Price-Robertson and Bromfield 2011:3; Gillingham and Bromfield 2008:22). Whenever a child known to state agencies dies, the question that arises is, how much more public funding is to be spent on the child protection system and whether this makes a real difference in protecting children from harm in vulnerable families who distrust, and refuse to engage with, CS and other human services. The distance between state social workers and the family is also framed by families' distrust of CS, which is understandable to some extent given that much of child protection work is negatively associated with child removal.

\section{Bridging the gap}

It is possible, though, to think laterally about this problem, such as considering ways to bridge the gap between the state and troubled families in which children might be at risk. Specifically, the contention that the state is too removed from these families has, to some extent, been addressed by the national framework for protecting children, which endorses a collaborative and integrated nationwide approach to child protection. This approach intends to involve the assistance of the wider community including professionals, community members, families and voluntary organisations (Council of Australian Governments 2009:8). While reforms are being undertaken in individual states including New South Wales, it is worth considering ways to heighten social awareness of the framework's message among vulnerable and disadvantaged communities, particularly for those living in regional areas.

For example, one way to harness the assistance of the wider community might be to explore ways in which community members can be trusted to act in a positive way as 'social guardians' to bridge the gap between the state and these families in which the children might be at risk. Social guardians are people who look out for each other, such as his or her neighbour's children at the park or at the shopping centre (Sampson, Eck and Dunham 2010:39). They may provide a support network against social isolation, which is one 
defining characteristic of abusive and neglectful parents (Vinson, Baldry and Hargreaves 1996:525). A 'guardian' could adopt the role of grandparents or aunts and uncles and provide alternate ways of dealing with situations where a parent is finding it difficult to cope. This could be an option that explores the widening and/or strengthening of existing policies that are grounded in a community prevention approach. Such an approach may consider harnessing the 'collective efficacy' of its residents to intervene when there are identifiable signs of abuse and neglect in children (Sampson et al 1997:919, 923). 'Collective efficacy' refers to cohesion among neighbourhood residents to act collectively under conditions of social trust and shared expectations for informal social control of public space (Sampson and Raudenbush 2001:1). Even though as a concept it is appealing, it is not without difficulties. For example, collective efficacy may not work since child neglect, abuse and filicide are committed within the family in the privacy of the home (Mouzos and Rushforth 2003:1-3). A counterargument is that because most perpetrators would have had some prior contact with state or non-governmental agencies (Wilczynski 1997:241), community and family members and family support services are the next best pre-emptive option after professionals, and they will be equally positioned to identify signs of potential problems. Additionally, it is highly possible that there will be opportunities for physical manifestations of neglect and abuse in a child to be revealed to close family and community members with whom the family or the child interact with on a regular basis, and possibly in social and public spaces such as schools.

An example of where the lack of visibility of a child in the community raised alarm bells was the case of Ebony. Ebony had not been seen at school for an extended period of time, which resulted in a number of reports made to CS and the Department of Education, some of which were made by community members (NSW Ombudsman 2009a:4). Her gradual disappearance from public view was also noticed by a neighbour, a person who knew the family, who rang CS with concerns that Ebony's window was boarded up and that the other children were rarely seen (NSW Ombudsman 2009a:45).

Particularly in vulnerable and disadvantaged neighbourhoods, having a close-knit, trusting and supportive network such as this, which emphasises the building of long-term social ties within the community, may help to establish the socially inclusive approach suggested by Caruana and McDonald (2011:3-5), and build resilience in vulnerable families. It would also reflect the shared community responsibility endorsed by the national framework (Council of Australian Governments 2009). A society with more of these kinds of people in the community can provide proximate physical and emotional support to vulnerable families who may lack the benefit of an extended family, especially if some of these families have reservations about approaching CS or are themselves under significant stress. In local, and perhaps troubled, communities like Mount Druitt, Kiesha's family's home suburb, the concept of social guardianship may be appealing because of the close emotional and physical proximity of its residents.

There are already some voluntary organisations working in this way, for example Aunties \& Uncles (<http://www.auntiesanduncles.com.au/ $>$ ), and various home visiting support services for isolated or struggling parents such as Women's Health West (2010) and Early Childhood Services (Yooralla). Not only can extended family and substitute supports, such as those mentioned above, provide respite and assistance, but they can be alert to situations of danger for the child. It is not unusual in cases where the child is eventually killed or dies, such as in the cases of Ebony and Dean, for extended family or community members to have alerted CS to risks of significant harm only to be ignored or dismissed (NSW Ombudsman 2009b:9; Sim 2009:244). Even though there may be identifiable benefits to establishing social guardianship in the community, there are also challenges and barriers, including: 
difficulties with finding such persons willing to take on the role of the social guardian, especially in disadvantaged and troubled communities; and difficulties with the imposition of informal social control on familial activities that may traditionally be considered as 'private', such as the discipline of children.

It is not yet known whether family or community members raised concerns about Kiesha, although it appears quite likely that she was known to CS (Australian Associated Press 2010). While it may be far from clear whether this particular proposal would have made a difference in Kiesha's circumstances, it may still be worthwhile to further explore the aspects of CS that encourage the strengthening of community and social ties between the family and the state through the community, especially within disadvantaged neighbourhoods and communities. Whether it is finding ways to create a socially inclusive service-oriented policy within family support services such as identified by Caruana and McDonald (2011:9), or to develop a shared collective identity through collective and symbolic representations of community life to strengthen social cohesion within communities such as identified by Wickes (2010:439), these represent socially inclusive pathways and practices that are surely worthy of more in-depth research.

While NSW has already done much under the Keep Them Safe system ( $<$ http://www.keepthemsafe.nsw.gov.au/>), a greater community involvement would also be in accordance with international developments in child protection. For example, the best interest of the child principle in the 1990 United Nations Convention on the Rights of the Child, although not directly implemented in Australia, is reflected in domestic laws, such as the Family Law Act 1975 (Cth); and the 1996 Hague Convention on Jurisdiction, Applicable Law, Recognition, Enforcement and Co-operation in respect of Parental Responsibility and Measures for the Protection of Children, which entered into force for Australia through the Family Law (Child Protection Convention) Regulations 2003 (Cth). These developments legally mandate state intervention to protect children from harm and neglect (Lamont and Bromfield 2010) by ensuring the best interest of the child principle is followed. As such, heightening social awareness of the visibility of children with a focus on their safety and wellbeing in both public and familial spaces is important; and necessary to secure the child against the hidden risks of child endangerment as demonstrated by the cases of Kiesha Abrahams, Dean Shillingsworth and Ebony.

\title{
Conclusion
}

Nevertheless, one of the lessons to emerge from reflecting on these kinds of cases is that CS needs to make sure that it is actively listening to the concerns of family and community members and friends and taking their concerns more seriously. In light of the recent changes to the CYPA, the focused approach taken by CS and the national framework on child protection, it is perhaps time to explore alternative ways to empower the community through $\mathrm{CS}$ to provide more comprehensive, supportive and socially inclusive networks that re-engage with vulnerable families and that secure children's safety and wellbeing in both their social and familial environments, but where the efforts of the state and parents may sometimes be limited.

\section{Janice Sim}

\author{
PhD candidate, Sydney Law School, University of Sydney; Sessional \\ academic, School of Criminology and Criminal Justice, Griffith University
}




\section{Legislation}

Children and Young Persons (Care and Protection) Act 1998 (NSW)

Family Law Act 1975 (Cth)

Family Law (Child Protection Convention) Regulations 2003 (Cth)

\section{International Conventions}

Hague Convention on Jurisdiction, Applicable Law, Recognition, Enforcement and Co-operation in respect of Parental Responsibility and Measures for the Protection of Children, 19 October 1996 (entered into force 1 January 2002)

United Nations Convention on the Rights of the Child, GA Res 44/25, 44th sess, 61st mtg, UN Doc A/RES/44/25 (12 December 1989) (entered into force 2 September 1990)

\section{References}

Aunties \& Uncles $<$ http://www.auntiesanduncles.com.au/ $>$

Australian Associated Press (2010) 'Ombudsman intervenes in case of missing six-year-old Kiesha Abrahams', The Australian (online), 5 August 2010 $<$ http://www.theaustralian.com.au/news/nation/ombudsman-intervenes-in-case-of-missingsix-year-old-kiesha-abrahams/story-e6frg6nf-1225901620566>

Australian Associated Press (2011a) 'Kiesha's stepfather pleads guilty', The Sydney Morning Herald (online), 16 December $2011<$ http://news.smh.com.au/breaking-newsnational/kieshas-stepfather-pleads-guilty-20111216-1oxbp.html>

Australian Associated Press (2011b) 'Kristi Anne Abrahams "distraught”, appears in court charged with daughter Kiesha's murder', Herald Sun (online), 1 May 2011 $<$ http://www.heraldsun.com.au/news/national/abrahams-distraught-appears-in-court/storye6frf716-1226046875253>

Caruana C and McDonald M (2011) Social inclusion in the family support sector, Australian Family Relationships Clearinghouse Briefing Paper No 19, Australian Institute of Family Studies

Council of Australian Governments (2009) Protecting Children is Everyone's Business: National Framework for Protecting Australia's Children 2009-2020, Australian Government, Canberra

Cowdery N (1999) 'Mandatory Life Sentences in New South Wales', University of New South Wales Law Journal 22(1), 290-4

Gillingham P and Bromfield LM (2008) 'Child protection, risk assessment and blame ideology’, Children Australia 33(1), 18-24

Lamont A and Bromfield L (2010) 'History of Child Protection Services', National Child Protection Clearinghouse Resource Sheet, Australian Institute of Family Studies 
Lawrence C (2011) 'Parents of Kiesha Abrahams refused bail on murder charges', Penrith City Star (online), 29 April $2001<$ http://www.penrithstar.com.au/news/local/news/general/ parents-of-kiesha-abrahams-refused-bail-on-murder-charges/2148206.aspx?src=rss>

Liu S and Thomas S (2011) 'Packed court awaits verdict on Kiesha's Abrahams case', Mt Druitt Standard (online), 29 April $2011<\mathrm{http}: / / \mathrm{mt}$-druitt-standard.whereilive.com.au/ news/story/packed-court-awaits-verdict-on-kiesha-abrahams-case/>

Mouzos J and Rushforth C (2003) 'Family Homicide in Australia', Trends \& Issues in Crime and Criminal Justice No 255, Australian Institute of Criminology, Canberra

NSW Child Death Review Team (2008) Trends in the fatal assault of children in NSW: 1996-2005, New South Wales Commission for Children \& Young People

NSW Ombudsman (2006) Report of Reviewable Deaths in 2005, Volume 2: Child Deaths, Sydney, NSW

NSW Ombudsman (2009a) The death of Ebony: The need for an effective interagency response to children at risk, Sydney, NSW

NSW Ombudsman (2009b) The death of Dean Shillingsworth: Critical challenges in the context of reforms to the child protection system, Sydney, NSW

Price-Robertson R and Bromfield L (2011) Risk assessment in child protection, Resource Sheet March 2011, National Child Protection Clearinghouse

Sampson R, Eck JE and Dunham J (2010) 'Super controllers and crime prevention: A routine activity explanation of crime prevention success and failure', Security Journal 23(1), 37-51

Sampson R and Raudenbush S (2001) 'Disorder in Urban Neighbourhoods: Does it Lead to Crime?', National Institute of Justice Research in Brief, February 2001, US Department of Justice, Washington DC

Sampson RJ, Raudenbush SW and Earls F (1997) 'Neighbourhoods and Violent Crime: A Multilevel Study of Collective Efficacy', Science 277, 918-24

Sim J (2009) 'Loving Fathers? Implications of State Intervention', University of Tasmania Law Review 28(2), 242-64

Vinson R, Baldry E and Hargreaves J (1996) 'Neighbourhoods, Networks and Child Abuse', British Journal of Social Work 26, 523-43

Wickes RL (2010) 'Generating Action and Responding to Local Issues: Collective Efficacy in Context', The Australian and New Zealand Journal of Criminology 43(3), 423-43

Wilczynski A (1995) 'Risk Factors for Parental Child Homicide: Results of an English Study’, Current Issues in Criminal Justice 7(2), 193-222

Wilczynski A (1997) 'Prior Agency Contact and Physical Abuse in Cases of Child Homicide', British Journal of Social Work 27, 241-53

Women's Health West (2010) <http://www.whwest.org.au/research/melton.php>

Yooralla $<$ http://www.yooralla.com.au/index.php> 